\title{
Palestinian Nation Branding via Public Diplomacy
}

\author{
Dalal Iriqat \\ Arab American University, Ramallah, Palestine
}

The term "branding" is still contested when linked to nations; colleagues in Palestine would argue that the term "promotion" could be of a more positive impact; in fact, this paper will examine this issue as scholars automatically link "branding" to products, business, and trade. It is not easy to imagine the nation as a brand; a nation cannot re-make itself, like a company launching a new product. Branding a nation is inspired by its national identity which started to evolve with the evolution of the nation states; it heavily relies on people's attachment to a shared land, shared history, shared language, shared culture, religion, clothing, behaviours, values, attitudes, or positions in dealing with internal and external variables. It is crucial to distinguish the identity for a nation which is usually done through studying the elements depending on which a nation promotes itself using public diplomacy. Public diplomacy is a soft power's key instrument which we cannot ignore; in soft power, the narrative and the reality have to reflect each other. A nation's identity is partly inherited from history and partly a continuing construction; there are aspects of national reputation which can be altered, for better or worse, by choice of actions, words, and images. Even the inherited parts of national reputation are open to revision as time goes by, states have gun a long way in their nation branding and Palestine cannot remain indifferent. This paper aims to address the importance of Palestinian national branding and to further shed light on how this could be done. Based on examples of other successful countries-case studies, the paper shall introduce a number of elements that shape a national identity; those elements are expected to inspire scholars and policy-makers in determining what is worth promoting in Palestine that would lead to successful branding of Palestine as a nation. In branding for Portugal, Cristiano Ronaldo, the soccer player was determined to be a national brand; the Portuguese chose to brand themselves with his initials CR7. Today, if you read, hear, or visit Portugal, you will find a lot related to CR7, whether we like soccer or not, CR became an attractive brand for his country. For their nation branding, Portuguese chose tourism, cuisine, culture, and sports rather than their history of conquering the world, and this paper will be inspired by this example and others. In Palestine, not much work had been put on nation branding; therefore, this paper will introduce the concepts and will try to examine how important it is for serving the national cause and the strategic national goals, in doing so, the paper will try to answer the following questions: What is nation branding? How is public diplomacy related to nation branding? Can public diplomacy replace nation branding? What is the image of Palestine and Palestinians abroad? How are we seen by others vs. how do we wish to be seen? Does Israel play a role in branding Palestine and Palestinians internationally? Is it important to consider a national brand/s for Palestine? What is the Palestine that we aspire to promote?

Keywords: Diplomacy, Nation Branding, Public Diplomacy, Palestine, Soft Power, National Identity, Narrative 


\section{Introduction}

\section{Chapter 1: A Theoretical Framework}

This chapter will introduce the reader to the concept of branding of a nation; moreover, light will be shed on public diplomacy, a key instrument as soft power, then a discussion will be presented on the relationship of the two terms and how they could serve each other in finally influencing the foreign policy and positively changing the image of one's nation and specifically for Palestine.

\section{Nation Branding}

The concept consists of two words: "nation", here we are talking about the people (citizens, outsiders, refugees, etc.) and "branding", which is a purely business term that was later introduced to the area of politics and diplomacy; by applying this concept, we try to answer the questions: What do we want to promote? And what do nations promote?

In this paper, the theoretical framework will heavily rely on the work of the pioneers of nation branding naming (Szondi, 2009):

- Simon Anholt;

- Wally Olins;

- Tom Fletcher;

- Joseph Nye.

As mentioned earlier in the abstract, branding a nation is inspired by its national identity. Yes, national identity is largely a matter of stereotypes, familiar images, and associations. Most national identities are very static. Simon Anholt, who is often referred to as the originator of nation branding, lists six channels of influence as the main elements of national identity, or as he calls it, competitive identity. Those are: (1) people; (2) culture; (3) investments; (4) policy; (5) brands; and (6) tourism.

Anholt's list leaves out at least one important element of national reputation, and that is history. A country's political history is a major factor, the big things that the nation has done or failed to do and the things that it has stood for or perhaps betrayed (Anholt, 2007).

The above list explains why Italy, for example, ranks high in nation branding surveys, given its strengths in culture, tourism, brands, and the bright image of its people. However, nation branding is controversial, a British marketing guru; Wally Olins is one of the first to use the term "branding" for promoting a national identity. Olins believed that it is wise to adopt business terms to politics and diplomacy; nevertheless, some prefer to refer to it as public diplomacy; instead, those were offended by the term as it reflected that the nation was a PRODUCT! When the author first talked about branding, the Palestinian nation, and the nation as a brand, a number of colleagues disagreed and suggested the use of other political terms; the term is still contested among scholars in Palestine and resistance to the term is huge because of its business dimension; despite the differences, we cannot deny that the term is catchy and attractive, and accommodates today's needs and trends; Palestine cannot remain indifferent! The following quote reflects the Palestinian situation.

When I first talked and wrote about branding the nation and the nation as a brand in the 1980s, most commentators could barely conceal their bile [hostility]. The idea they had was that branding the nation was the equivalent of treating the nation like a washing-up liquid in a supermarket. There is in reality nothing new about national branding, except the word 
"brand" and the techniques that are now used, which derive from mainstream marketing and branding techniques. (Wally Olins $)^{1}$

For the late Wally Olins, nation branding was key to economic growth in a globalized world; Olins argued that just as Bismarck invented the values that define modern Germany ("efficiency", "engineering excellence", and "hard work"), so nations that want to escape from historic stereotypes can do so, if they take their brands seriously. New Zealand's shift from post-colonial to service and tourism hub is a good example of this. This is an unusual way of looking at history; liberty, equality, and fraternity are arguably one of the most attractive meta-messages ever written, where Olins also saw the importance of the French national brand in politics and not only in perfumes. As John Williams elaborates: Nations are fighting for influence, fighting for political power, fighting for cultural power, and fighting for all kinds of spaces in people's minds (Williams, 2012).

Tom Fletcher puts the national story at the heart of what he describes as magnetic power, which is close in meaning to Joseph Nye's attractive power on which we will shed light later in this paper. The question here is what does a nation need in order to be positively branded, imaged, or seen by others. Generally speaking, a nation needs:

1. Attractive national story.

2. Narrative, which encourages others to support, or not to obstruct its strategic objectives.

3. Soft power (it is about international politics and the power to influence what happens).

In a process of nation branding, it is wise to go back to the manageable elements on which we could rely and are subject to change: Leadership, culture, cuisine, individual accomplishments, fashion, and design $\rightarrow$ embroidery, agriculture, and products.

\section{Significance of National Branding (National Image)}

In the recent years, the debate on systematic national image building has become an important topic of interest among academics and policy-makers, inferring the awareness among the national governments on the significance of national image in a globalized world. The demand for national image has led to different activities leading to systematic construction of national image by national governments. The concern with national image building can serve dual purpose if conducted effectively, creating domestic political support and improving one country's international influence. The current preoccupation with systematic construction of national image seems to serve the latter purpose, in a world where nation states desire to integrate with global markets, to participate in global affairs than ever and to improve the country's status on the world stage. This surge in the demand for national image; that is, how a country is perceived has become a significant variable in defining a country's international relations and is as a result of the changes in the nature and conduct of international relations.

The conception of an image means not only the conception of the image at present, but also aspects of its past and future expectations. National image, then, can be defined as the cognitive representation that a person holds of a given country, what a person believes to be true about a nation and its people. On the discussion of the national image building, primarily two levels of analysis are possible on the grounds for whom the image is constructed; the first is for the domestic population and the second is for the "foreign" audience; however, both

\footnotetext{
${ }^{1}$ Quote from William, John, Strategic Communications course at BZU at Abu Lughod Institute for International Studies 2014-2015.
} 
are linked to each other. ${ }^{2}$

As argued by Nye, in the age of information technology and communication revolution, the way in which power in the international politics is understood and defined has undergone drastic change. The power of persuasion or attraction which Nye defined as "soft power" is equally important as hard power resources of military and economy. According to him, in the information age dominated by global information and communication, story wins are equally or even more important than army wins, hence to emphasize on the importance of national narratives. The understanding of Nye on soft power is of general attitude, perception, or image that a country's citizens have on a foreign country, mainly conceptions of favorability and positives toward a foreign country (Nye, 2004).

Some might argue that nations have always engaged in branding activities, although the phenomenon has not always been labelled as such. Though the term "nation branding" is a recent introduction, the concept is quite old as an idea on nation argued by Wally Olins (2002). Olins observed nations are already de facto brands, as they reflect their assets, attributes, and liabilities to a public at large, whether intentionally or not. Nation branding is largely perceived as a rhetorical equivalent to national identity, hence there is nothing particularly novel about the concept of branding the nation. According to Olins, just only the word "brand" is new. National image, national identity, and national reputations are all words traditionally used in this arena and they do not seem to provoke the same hostility as the word "brand".

Nation branding has received some scholarly interest lately; those writings on the subject are also heavily involved in the practice of nation branding, most notably Simon Anholt and his Nation Brand Index. ${ }^{3}$ Nation branding is concerned with a country's whole image on the international stage covering political, economic, and cultural dimensions. As an emerging area of interest, nation branding is driven largely by practitioners and is yet to be clearly conceptualized. The following definition demonstrates nation branding as the mere application of branding strategies and tools for nation states: "Nation branding concerns applying branding and marketing communications techniques to promote a nation's image" (Fan, 2006, pp. 5-14). This definition also highlights that nation branding is concerned with image promotion; Gudjonsson, an Icelandic brand practitioner defines nation branding in a similar way but he identifies the government as the initiator of branding, acknowledging its indirect involvement and influence: Nation branding occurs when a government or a private company uses its power to persuade whoever has the ability to change a nation's image. Nation branding uses the tools of branding to alter or change the behaviour, attitudes, identity, or image of a nation in a positive way. Fan provided a definition of nation branding which encapsulates the relationship between nation branding and national image management; nation branding is a process by which a nation's images can be created, monitored, evaluated, and proactively managed in order to improve or enhance the country's reputation among a target international audience (Gudjonsson, 2005).

A close examination of some major definitions ${ }^{4}$ of the nation branding concept shows significant differences in the focus and purpose or outcome of branding the nation:

\footnotetext{
2 Jojin, John. "Theory and Practice of 'Nation Branding'-Revisiting Public Diplomacy: Reflections from Australian and Indian Experience". Academia, 2.

${ }^{3}$ It is an index based on the concept of measuring the global perception of a country in several spheres developed by Simon Anholt, now called The Anholt-GfK Roper Nation Brands Index. For more information, see http://www.gfkamerica.com/practice_areas/roper_pam/nbi_index/index.en.html.

${ }^{4}$ Cited in Ying Fan, Branding the nation: Towards a better understanding, Brunel Business School Brunel University Uxbridge, London, p. 4, available online at https://core.ac.uk/download/pdf/336086.pdf.
} 
- To remold national identities (Olins, 2005);

- To embrace political, cultural, business, and sport activities (Jaffe \& Nebenzahl, 2001);

- To promote economic and political interests locally and internationally (Rendon, 2003; Szondi, 2007);

- To alter, improve, and enhance a nation's image or reputation (Gudjosson, 2005; Fan, 2006, 2008b, 2009);

- To enhance one nation's competitiveness (Anholt, 2007).

\section{Public Diplomacy: A Soft Power}

Public diplomacy is one of soft power's key instruments, the big difference between public diplomacy and commercial branding is that it is much easier for companies, simply because they are offering something those audiences actually want to buy and they are offering products not symbols and ideas. A nation cannot re-make itself, like a company launching a new product. In soft power, as in all forms of strategic communication, the narrative and the reality have to reflect each other (Williams, 2012). Soft power is using national identity as an instrument of strategy. A nation's identity or reputation is about the country as a whole, individuals and groups not restricted on its government's actions and personalities.

The term "soft power" was invented by Joseph Nye, a distinguished political scientist at Harvard, who first used it in this phrase in 1990: "When one country gets other countries to want what it wants-[that] might be called co-optive or soft power". 5

Had he chosen the term co-optive power, it would not have attracted much attention; the strength of the idea is in the neatness of the phrase "soft power" and means the ability to get the outcomes one wants. It is important to attract others and not only to force them to change by threatening military force or economic sanctions; soft power is about shaping the preferences of others. ${ }^{6}$

So, soft power is a form of strategic communication, which verb, to shape, is relevant for this paper: shaping the narrative, shaping the way the situation is understood, shaping the way the strategic choices are framed, and shaping the way others see us. If we can achieve these things, then we have soft power. John Williams, a former senior consultant on the British Support Team in Palestine for a number of years explained that the British team knows from polling in Palestine that Britain is associated with high quality education, including through Chevening Scholarships; education is a great force of soft power. The thousands of students who come to Britain every year and take home good impressions are a source of good national reputation. ${ }^{7}$

Marsh and Williams explain how Nye expresses his idea in five words: Soft power is attractive power. In more detail, he says that "soft power grows out of our culture, out of our domestic values and out of our foreign policy". So, it is grounded in the same place as strategy: in values. Perhaps the greatest modern battle of soft power was the contest between the United States and the Soviet Union from 1945 to 1990. It was a contest of military and economic hard power, but it was also a battle of values; Communism attracted the West, more so in Europe than in the United States; on the other hand, American and European values of freedom were

\footnotetext{
5 Kevin Marsh \& Williams John. Strategic communication, bound to lead: The changing nature of american power. Available online

https://books.google.ps/books?id=ZARMDwAAQBAJ\&pg=PA101\&lpg=PA101\&dq=\%E2\%80\%A2+Kevin+Marsh,+Williams+J ohn.+Strategic+Communication, + Bound+to+Lead:+The+Changing+Nature+of+American+Power.\&source=bl\&ots=67JSAfTwo V\&sig=ACfU3U0xiUAwdVlt0vFy60gsKjcJEv17Sg\&hl=en\&sa=X\&ved=2ahUKEwiD342guZzgAhUBEVAKHZfYBoIQ6AEw AHoECAYQAQ\#v=onepage \&q=\%E2\%80\%A2\%20Kevin\%20Marsh\%2C\%20Williams\%20John.\%20Strategic\%20Communicati on $\% 2 \mathrm{C} \% 20 \mathrm{Bound} \% 20$ to $\% 20 \mathrm{Lead} \% 3 \mathrm{~A} \% 20 \mathrm{The} \% 20 \mathrm{Changing} \% 20 \mathrm{Nature} \% 20 \mathrm{of} \% 20$ American $\% 20$ Power.\&f=false.

${ }^{6}$ Ibid.

${ }^{7}$ Cited in Williams lectures, BZU, ibid.
} 
attractive to many in the Soviet empire. ${ }^{8}$

\section{Public Diplomacy Vs Nation Branding}

Public diplomacy can be influenced by the history and culture of the particular country; public diplomacy's aim is to inform and engage individuals and organizations overseas, in order to improve understanding of, and influence for, their country in a manner consistent with governmental medium- and longterm goals, so basically, it is not the role of the government; but rather the role of individuals who can through their talents, skills, or connections, and to help in changing the public opinion in their respective hosting countries which will automatically influence the foreign policy of that given country. ${ }^{9}$

Table 1

Traditional Public Diplomacy Vs Contemporary Public Diplomacy

\begin{tabular}{|l|l|l|}
\hline & Traditional public diplomacy & $\mathbf{2 1}^{\text {st }}$ century public diplomacy \\
\hline Conditions & Conflict, tensions between states & Peace \\
\hline Goals & $\begin{array}{l}\text { To achieve political change in target countries by } \\
\text { changing behavior }\end{array}$ & $\begin{array}{l}\text { Political and economic interest promotion to } \\
\text { create receptive environment and positive } \\
\text { reputation of the country abroad }\end{array}$ \\
\hline Strategies & Persuasion managing publics & $\begin{array}{l}\text { Building and maintaining relationships Engaging } \\
\text { with publics }\end{array}$ \\
\hline Direction of communication & One-way communication (monologue) & Two-way communication (dialogue) \\
\hline Research & Very little, if any & $\begin{array}{l}\text { PD based on scientific research where feedback } \\
\text { is also important }\end{array}$ \\
\hline Message context & Ideologies interests information & Ideas values collaboration \\
\hline Target audiences (publics) & $\begin{array}{l}\text { “general” public of the target nation; sender and } \\
\text { receivers of messages }\end{array}$ & $\begin{array}{l}\text { Segmented, well-defined publics }+ \text { domestic } \\
\text { publics; Participants }\end{array}$ \\
\hline Channels & Traditional mass media & Old and new media; often personalized \\
\hline Budget & Sponsored by government & Public and private partnership \\
\hline
\end{tabular}

Nation branding occurs when an official and governmental body or a private company works to persuade whoever has the ability to change a nation's image, it could be done in a campaign style. Nation branding uses the tools of branding to alter or change the behavior, attitudes, identity, or image of a nation in a positive way (Szondi, 2009). Nation branding concerns applying branding and marketing communications techniques to promote a nation's image abroad.

The following table introduced by Szondi to compare nation branding and public diplomacy.

\footnotetext{
${ }^{8}$ Cited in Kevin \& Williams, ibid.

9 See Table 1, highlighting that nation branding is concerned with image promotion by comparing between traditional and modern public diplomacy. The table compares traditional public diplomacy and the 21 st century public diplomacy; many countries are still following the traditional public diplomacy model. The European Union's emerging public diplomacy is an example of the 21 st century public diplomacy.
} 
Table 2

Public Diplomacy Vs Nation Branding

\begin{tabular}{|c|c|c|}
\hline & Public diplomacy & Nation branding \\
\hline Goal & Promoting political interest & Promoting (mostly) economic interest \\
\hline \multirow{3}{*}{ Context } & $\begin{array}{l}\text { Politicised, focus, and priorities may change with } \\
\text { change of government }\end{array}$ & $\begin{array}{l}\text { De-politicised, general agreement among actors and } \\
\text { political parties (but in some cases it is politicised) }\end{array}$ \\
\hline & Identity driven & Image driven \\
\hline & Driven by international relations and culture & Driven by marketing and consumerism \\
\hline \multirow{3}{*}{ Targeted at } & Publics/stakeholders who are active & Mass/consumers who are passive \\
\hline & Citizens & Consumers (of images, products, and places) \\
\hline & Targeted at key geopolitical countries & Applicable to any countries, more universal \\
\hline Direction & Foreign publics & $\begin{array}{l}\text { Both foreign and domestic audiences. Without the } \\
\text { consent of domestic audiences it is doomed to fail }\end{array}$ \\
\hline $\begin{array}{l}\text { Role of } \\
\text { government }\end{array}$ & $\begin{array}{l}\text { Initiator as well as sender of messages, government has } \\
\text { more control over message }\end{array}$ & $\begin{array}{l}\text { Government could be the initiator but rarely the sender } \\
\text { (danger of propaganda) less or no government control }\end{array}$ \\
\hline Actors & $\begin{array}{l}\text { State and non-state actors government, governmental } \\
\text { organizations, embassies, Ministry of Culture; Ministry } \\
\text { of Foreign Affairs, Cultural Institutions, NGOs, } \\
\text { diasporas }\end{array}$ & $\begin{array}{l}\text { National tourist boards, travel agencies; investment } \\
\text { promotion and export agencies; trade boards, chambers } \\
\text { of commerce, multinational organisations, which are all } \\
\text { multipliers }\end{array}$ \\
\hline \multirow{5}{*}{ Strategies } & Relationship building and maintaining & \multirow{2}{*}{ Image management } \\
\hline & Trust building & \\
\hline & Emphasis on substance and content & Emphasis on visual and symbolic elements \\
\hline & $\begin{array}{l}\text { Decentralised approach, in different target countries } \\
\text { different strategies and activities tailored towards local } \\
\text { audiences }\end{array}$ & $\begin{array}{l}\text { Centralised approach, driven by the brand essence } \\
\text { (one-size-fits all) tailored towards a global and } \\
\text { homogenous audience }\end{array}$ \\
\hline & $\begin{array}{l}\text { Focus on both positive and negative elements that can } \\
\text { connect people and cultures }\end{array}$ & $\begin{array}{l}\text { Focus exclusively on positive and "marketable" } \\
\text { elements of a country's culture and people }\end{array}$ \\
\hline Tactics & $\begin{array}{l}\text { Exhibitions, international film festivals, exchange } \\
\text { programmes, language learning promotion, networking, } \\
\text { anniversaries, PMs, foreign affairs ministers' and other } \\
\text { politicians' articles in foreign daily newspapers, genuine } \\
\text { events }\end{array}$ & $\begin{array}{l}\text { Logo and slogan; country advertisements in leading } \\
\text { international TV channels, sponsored pages in leading } \\
\text { international magazines; e-marketing, web portals; and } \\
\text { press tours, brochures, pseudo-events }\end{array}$ \\
\hline Media & $\begin{array}{l}\text { Mass media are less significant, their main role is in } \\
\text { presenting and interpreting information. Social media } \\
\text { are getting more important }\end{array}$ & $\begin{array}{l}\text { Relies heavily on mass media as the main channel. } \\
\text { Media are passive, usually carrying paid advertisements }\end{array}$ \\
\hline Budget & Sponsored by government & Public and private partnership \\
\hline Time frame & On-going, continuous & Ad hoc, campaign-driven \\
\hline Evaluation & Short-, middle- and long- term & Mostly long-term \\
\hline
\end{tabular}

To emphasize on the efficacy of practical aspects of public diplomacy and nation branding, Szondi offers five different views concerning the relationship between these two concepts as follows: 
(1) Public diplomacy and nation branding are distinct fields;

(2) Public diplomacy is a part of nation branding;

(3) Nation branding is a part of public diplomacy;

(4) Public diplomacy and nation branding are distinct but overlapping concepts;

(5) Public diplomacy and nation branding are the synonyms for the same concepts.

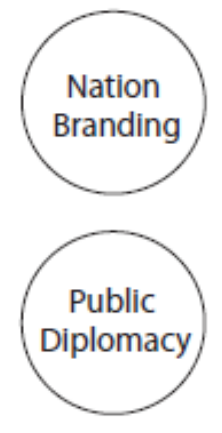

(1)

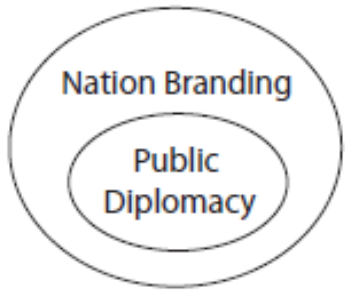

(2)

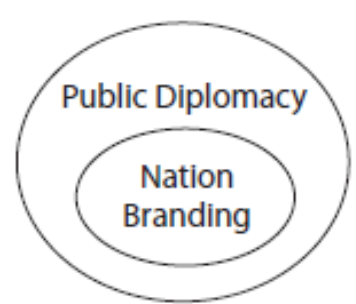

(3)

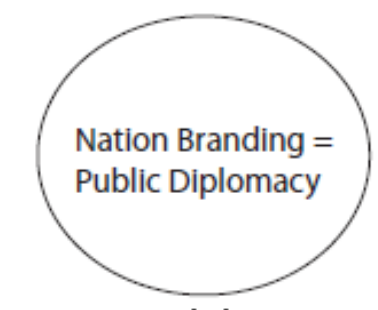

(5)

.

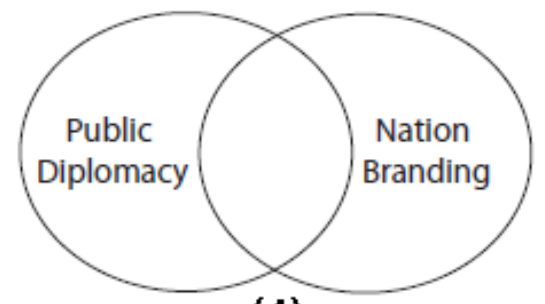

(4)

We agree with Szondi in his argument that nation branding and public diplomacy are not isolated concepts rather interlinked and mutually exclusive strategies of broader concept of national image management. Therefore, the conceptual aspects of nation branding and its conceptual linkages with public diplomacy are very close and go in parallel.

Chaker Khazal, Palestinian writer, is trying to market the story of the Palestinian refugees in an attractive way, through his recently released "Tale of Tala". During our interview, Khazal explained: The Palestinian refugees are totally forgotten and they live dire conditions, so he believes his story will refocus attention towards those refugees. When asked what we need to better brand Palestine, Chaker answered we need a nice story, younger people, diplomacy, and technology to represent the Palestinian cause. ${ }^{10}$ Chaker is an example of public diplomacy which the governmental bodies can employ to better brand the nation, echoing the story of Palestinian refugees through the eyes of a writer is normally much more convincing than the official story delivered by diplomats.

\footnotetext{
${ }^{10}$ Recorded Interview conducted in Ramallah on Saturday the 22nd September 2018, with Chaker Khazal.
} 


\section{Chapter 2: Case Studies to Inspire the Palestinian Case}

This chapter will introduce some examples from different countries to illustrate how focusing on certain areas in nation branding might be less harmful and more strategic than others. To better understand branding, let us look at different examples; in branding for Portugal, Cristiano Ronaldo, the soccer player was determined to be a national brand, the Portuguese chose to brand themselves with his initials CR7. Today, if you read, hear, or visit Portugal, you will find a lot related to CR7; clothing, hotels, restaurants, toys, and games all under his initials. Whether we like soccer or not, CR became an attractive brand for his country. For their nation branding, Portuguese chose tourism, cuisine, culture, and sports rather than their history of conquering the world.

Let us take Italy as another example: What comes to mind at the mention of Italy, well, most of us will think of: Pasta, Juventus and AC Milan, Leonardo da Vinci and Michaelangelo, Venice, Vivaldi and Verdi, Pizza and Parmesan cheese, basil and tomatoes and mozzarella, Julius Caesar, the Coliseum, ice cream, the Mafia, Rome, Islands, and Lamborghini. Some might think of Italian clothing brands depending on personal interests but it is not likely that any of us will think of Italian politics, for example, Italy has a wonderful national reputation for its culture, from renaissance painting to modern cuisine, but a very poor political reputation.

The way nation branding is done is the same as in all strategic communication by narrative. Tom Fletcher puts the national story at the heart of what he describes as magnetic power, which is close in meaning to Joseph Nye's attractive power: So, how do nation states use their magnetic power in the digital age? As introduced earlier, three ideas should be considered here: having a strong national story; knowing how to tell it, knowing how and when to mix the tools, and making full use of social media in public diplomacy. To have soft power, a nation needs an attractive national story, a narrative which encourages others to support, or not to obstruct, your strategic objectives. Soft power is not about marketing the nation's products or pulling in tourists, it is about international politics and the power to influence what happens. There is a difference between, on the one hand, national inventions that are used and admired, and which are elements of national reputation, and on the other hand, soft power: the ability to set the agenda and achieve your objectives without using force. The national reputation of the United States as the source of Apple, Facebook, Google, and other Silicon Valley style modern miracles, and the slogan "I have a dream", reflects America's cultural influence, exercised through products that almost define modern living, is what matters for a successful American nation branding, the cultural and commercial aspects of national reputation must be kept in perspective.

The astonishing success of Harry Potter, or the Royal Shakespeare Company, makes Britain a soft power superpower. Like Italy, the UK has many national assets; the Premier League and the Monarchy, which are important elements in shaping the nation brand of Britain and how it is perceived by others. If we think of two or three countries that might be described as soft power superpowers, we can start with Germany, which national reputation may be static year by year, but the transformation of Germany's over the decades has been heroic. This change has been founded on a self-aware national decision by millions of individuals acting to break with the past by accepting guilt, the "moral burden" of the barbarity of the Nazi era, it is remarkable after WWII how the guilt is internalized and becomes part of the German national identity. To a certain extent, this is the case with Poland that was stuck with the Holocaust narrative for a while. Germany is now the 2nd most admired country in the world after Canada, according to a BBC "country ratings" poll conducted by 
Globescan. ${ }^{11}$ The elements in building that reputation include the success of Germany's national brands, especially the cars which give Germany a strong association with positive qualities, like engineering excellence, reliability, and style. There was a turning point in Germany's reputation when Audi used a German language slogan which raises the "German-ness". In other words, German-ness was negative but they decided to put the German-ness back into the brand, it worked-the German-ness of Audi helped to sell the car. It cannot be contested nowadays that Audi as a German company is indeed the national identity of Germany, the whole idea and image of Germany became positive.

In the famous soft power or nation branding indexes, there is little movement year by year. In the best known of them, the US replaced Germany as No. 1 the previous year. That was the only change in the top 10, which is by the way: No. 3 Britain, No. 4 France, No. 5 Canada, No. 6 Japan, No. 7 Italy, No. 8 Switzerland, No. 9 Australia, and No. 10 Sweden. No Arab countries, nor African, nor South American. Of course, it all depends on what you are measuring. So, Germany has a positive national identity, perhaps the best in the world, linked to strong national brands that help define the country, and founded in an admirable way of dealing with historic national guilt. But what has this power of attraction given Germany in terms of soft power to achieve national objectives? Germany could not have become the dominant country in the European Union without this transformation of its national reputation. Obviously, the size and strength of Germany's economy are hard power factors in dominating the Union. It is not only the hard power of Germany's economy that gives it the leading role, but the soft power of its economic ideas. The deep admiration for Germany's economic record-as reliable and well-engineered as an Audi or BMW-gave Germany the soft power to persuade European nations and global financial institutions to want what Germany wanted. Israel is indeed following in the footsteps, by the fact that Israel is now seen as the Silicon valley of the Middle East, Israel succeeded in refocusing world attention from its occupation and military image into a more industrial and best service provider and excellent IT applications provider that the world needs. This explains how Israel succeeded in penetrating different regimes and especially those in the Arab or Islamic world.

\footnotetext{
11 A total of 17,910 citizens across 19 countries were interviewed face-to-face or by telephone between December 26, 2016 and April 27, 2017. Polling was conducted for BBC World Service by the international polling firm GlobeScan and its research partners in each country, together with the Program for Public Consultation (PPC) at the University of Maryland, see http://www.globescan.com.
} 
Net Ratings,* Average of 11 Long-Term Tracking Countries,** 2005-2017

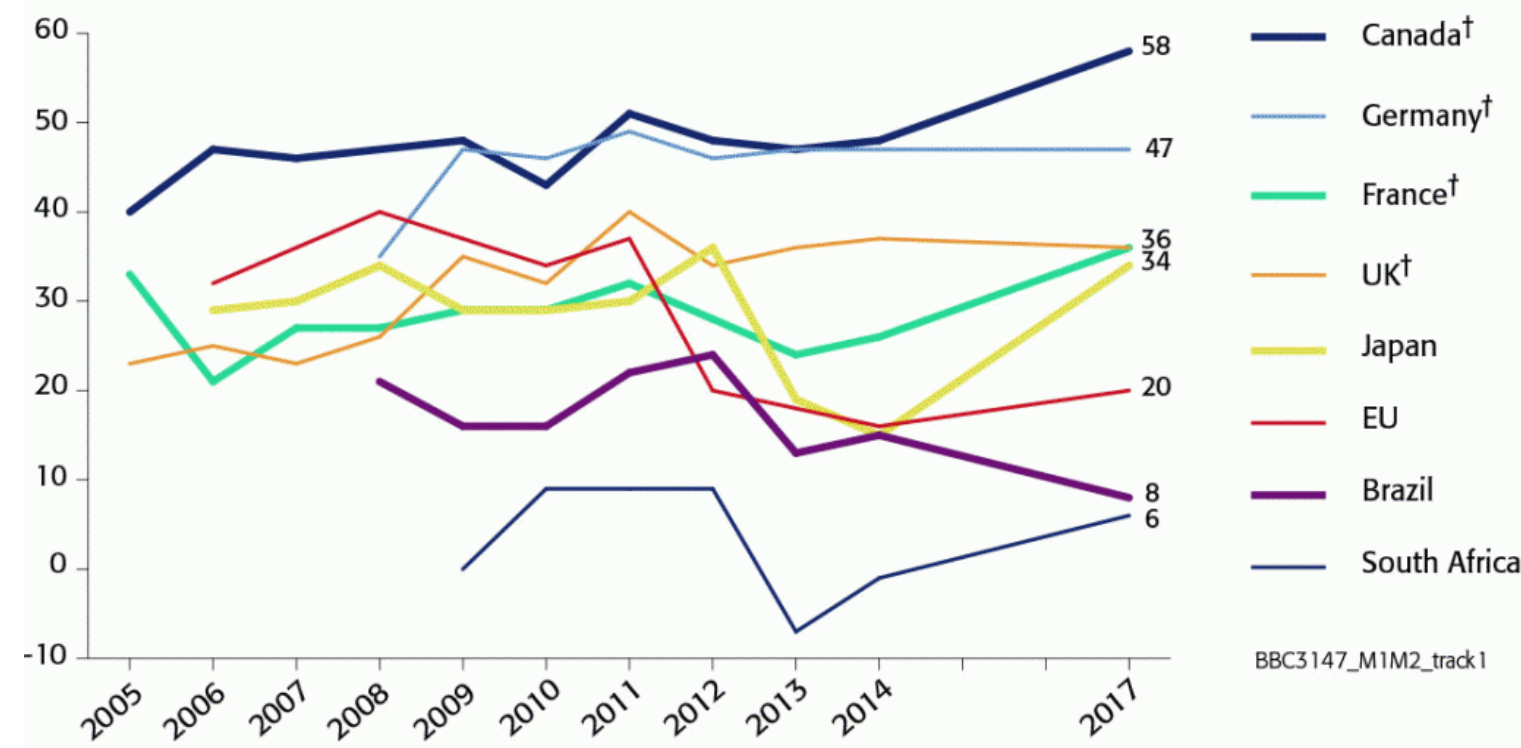

*"Mainly positive" minus "Mainly negative" ratings

**tong-term tracking countries include Australia, Canada, China, France, Germany, India, Indonesia, Mexico, Russia, UK, and USA.

Note: Average ratings exclude the target country's rating of itself, meaning some of the averages are based on 10 and not 11 countries.

These countries are marked with a dagger symbol $(\dagger)$.

Mexico is not a tracking country of views of Brazil in 2017.

Figure 2. Views of different countries' influence.

There is no point in trying to separate hard and soft power, George Szondi elaborates they are usually both in play, they are "inextricably linked", public diplomacy is one of soft power's key instruments. The big difference between public diplomacy by governments and commercial branding is that companies find it easier to be popular with their audiences simply because they are offering something those audiences actually want to buy (Szondi, 2009).

A nation cannot re-make itself, like a company launching a new product. In soft power, as in all forms of strategic communication, the narrative, and the reality have to reflect each other. Joseph Nye gave China as an example, while the 2008 Olympics was a success abroad, but shortly afterward China's domestic crackdown on human rights activists undercut its soft-power gains. The Shanghai Expo was also a great success, but it was followed by the jailing of Nobel Peace Laureate Liu Xiaobo. And for all the efforts to turn Xinhua and China Central Television into competitors for $\mathrm{CNN}$ and the $\mathrm{BBC}$, there is little international audience. According to a recent global poll by Pew Research,

perceptions of China are negative in most of the nations surveyed. Ratings for China have slipped in France, Spain, India, Italy, the UK, and Germany. Just 37\% of Americans express a favorable opinion of China, essentially unchanged from last year's 38\%. Only $11 \%$ of Japanese see China positively, little changed from the 9\% registered in $2015 .{ }^{12}$

As for America, Pew surveys throughout the Obama era have found largely positive attitudes toward the U.S.

${ }^{12}$ BBC global poll on country ranking index, Retrieved from http://www.bbc.co.uk/news/27685494. 
around the world, although there are notable exceptions, especially in the Middle East, according to the company's commentary on its latest polling. In Europe, the U.S. is seen favorably by $74 \%$ in Poland, $72 \%$ in Italy, 63\% in France and the Netherlands, 61\% in the UK, and 57\% in Germany-positive in all European countries surveyed except Greece, with only $38 \%$ favorable and a majority $(58 \%)$ unfavorable. So, although America's influence in the world rests on hard power, it has formidable soft power assets in its national reputation, as well as in its leader's favorability, though that could be about to change. In Europe, 77\% had confidence in President Obama, 59\% in Hillary Clinton, and 9\% in Donald Trump. We can be clear that American soft power had been affected after Trump came into the White House.

Does soft power matter, or is it an illusion in a world dominated by hard military and economic power? Yes, the author thinks soft power is fundamentally important. The best example in recent history, in which soft power was decisive, was the choice of countries of Eastern Europe to join the EU after the break-up of the Soviet Union. Any of them might have become a fascist dictatorship; Hungary and Poland are examples to see that the risk remains but instead they turned west and joined the EU. There was no military force involved though there was some economic power exerted, but more than anything this was a triumph of attractive power as those countries were drawn to the freedom and prosperity of Western Europe. It was a historic period in which the big strategic choice proved the wisdom of Joseph Nye's five-word definition: "Soft power is attractive power".

To conclude, from the cases studied here, the application model for nation branding adopted varies from country to country. As argued by Anholt the brand guru, it would be a mistake for a country not brand itself in a world of competing identities.

\section{National Identity \& Propositions for Palestine}

Before we conclude that it is important to try to answer the question on what the Palestinian nation should promote. Generally, we found it is common that nations try to shed light on one or more of the elements that shape a nation's identity-history, religion, national movements, regional belonging, culture, grassroots, individuals, human capital \& leadership, cuisine, fashion \& embroidery, industry, agriculture, and manufacturing \& products.

Starting with history \& religion: Some countries consider history for promoting their nation, in the Palestinian/Israeli context, we would argue that the historical argument is very sensitive, if we try to adopt history and religion as areas of focus to promote for Palestine, we will be met with the religious argument of who was here first! ${ }^{13}$ To further explain this point, it is important to remember the widely shared video produced by the Israeli Ministry of Foreign Affairs (MOFA) supporting Golda Maiir's narrative that there were never Palestinians on this land! This narrative deepens differences and feeds violence in the region and it is wise to avoid it. When it comes to religion, Palestinian scholars who had tried to work on narrative naming Dr. Ghassan Khatib, for example, would argue that part of the Palestinian identity is the religious holy identity. Christianity and Islam are rooted in this land and are a source of pride to a big majority of the Palestinian people; nevertheless, we think this element could have a counterproductive argument if we prioritize the

\footnotetext{
13 Affairs, Israeli Ministry of Foreign. "Israeli Ministry of Foreign Affairs". Welcome to the Home of the Jewish People. No matter who came knocking at the door, the Jews stayed put in their home-sweet-home, the Land of Israel, for 3,000 years, Retrieved from http://mfa.gov.il/MFA/IsraelExperience/VideoLibrary/Pages/Welcome-to-the-home-of-the-Jewish-people-6-October-20161006-1 06.aspx.
} 
historical or the religious narrative as to strengthen our argument. It is realistic to admit that there exist two narratives for religion and history, the question is: Do we want to focus on history? Who will win the historical argument? The author is using the Israeli ministry of FA campaign as an eye opener in order to understand Israel's role in branding for Palestinians abroad and how risky it could be for us if we choose to heavily rely on the historical narrative when we embark on working on Palestinian national branding. Talking about the elements of focus in promoting for one's nation, it is crucial to note that History and Religion are elements which are not easy to change or manage, but other elements, like leadership, culture, cuisine, accomplishments, fashion, embroidery, industry, agriculture, and products are always changing and those can be manageable in branding for nations.

Let us focus on the Palestinian identity, shedding light on the components of identity to try to answer if the Palestinian identity is a national, religious, regional, cultural, educational, or even social. The Palestinian national identity did not emerge with the PLO or after the Balfour declaration, the Palestinian identity existed long before as it has always been the holy land. Belonging to a city, the power of belonging to a city has gradually led to a collective identity. And this automatically leads us to the regional belonging, the question we need to address here is how others view us or how we are seen by others decide or shape our identity. Arab states have played a major role in shaping the Palestinian identity through the different strategies that each country has adopted towards the Palestinians, the question here is what the role of the Palestinians is in directing the Arab policies. Arab regional role in shaping Palestinian identity has led to introducing the Palestinians as refugees, victims, guerrilla fighters, stone throwers, poor, and beggars to the regional and international world. Whether we like it or not, the image of a Palestinian abroad is that of a stateless, ID less, and jobless.

If we look at the Anholt six elements: people, culture, investments, policy, brands, and tourism, we will easily discover that Identity for Palestinians is not only about the nation's image but about the political image of its leader and the human capital of its heroes. Some nations have seen major change in national identity under radical leadership, both for good and ill. For Palestine, maybe it is important to study the personality of Yasser Arafat as an icon and a symbol that presents a positive image of the Palestinian national narrative that symbolized resistance and perseverance, Arafat's name succeeded to be linked to the Palestinian struggle worldwide. Leaders or personalities are a human capital for Palestine, those include poets, artists, and the figures who managed to penetrate the international borders with the soft skill they are gifted; in order to counter the image of a victim, why not introduce the heroes? Palestinians are perceived poorly and with sympathy, in Palestine's nation branding, there exist a number of already established brands naming: Trio Joubran, three brothers musicians who have taken Oud to world class music; DAM, young Palestinian brothers who focus on conflict and poverty; Reem Bana, a singer, another icon in Palestinian music that went worldwide and managed to gather the love of millions around the globe; Athletes like Twin Skaters \& The Speed Sisters, the first ladies only speeding race group not only in the Arab world but also in the Middle East; poets and here it is not contested that Mahmoud Darwish, Ghassan Kanafani, and others had already brought Palestine to the world in different languages; a new kind of art is cartoons, Palestine is rich, Naji Ali, Mohamed Sabaaneh, and many others, their cartoons and posters that gained the attention and inspiration of the world; artists like Nabil Anani, Bashar Hroub, Tayseer Barakat, Laila Shawa, etc. who participate in famous world galleries, scholars like Edward Said, children heroes like Ahed Tamimi or Shadi, Ahmad, and the photographer Arine Rinawi, a young woman who managed to reshape the field of photography not only in Palestine and many others, those are 
humble examples of personalities that make Palestine unique and they are established brands which Palestine can utilize in its nation branding by introducing those talents and skills that Palestine can put on the international scene, things that other nations do not have a copy of, Palestinian human capital is a major investment in building a national brand for Palestine.

Tourism is another aspect especially the old cities, registered old cities or listed cities in the UNESCO world heritage record can be a good focus, in Palestine, Jerusalem, Hebron, Jericho, Batir, and Bethelehem have great significance in tourism, culture, history, and religion, for Palestine to consider branding itself with focus on those cities and what makes them unique is much needed to attract attention and to show that Palestine that we wish to promote.

Culture for Palestine is nothing but a treasure, the traditional dress "Thobe" that is hand embroidered; the Dabka dance, the cuisine, delicious food, and amazing hospitality are among other things that make Palestinian culture very attractive.

Education is unique in Palestine, Palestinians excelled in educational fields and have proved their proficiency in different countries and mainly inside Palestine, it can't be contested that higher education is a positive image of the Palestinian people hosting 13 universities in this turbulent atmosphere and providing state of the art academic and educational services is something to promote for Palestine.

For a nation to change its image, it needs first to change its behaviour. Then, equally important, it needs to tell the people in the world about the changes, images of a nation will not automatically change after the changes in reality, the way for a nation to gain a better reputation is to communicate to the international audience that how good you are, this practice is called nation branding. The government needs to focus on the treasures of talents that Palestine hosts, and communicate their stories in their own touchy tools which will positively influence the image of Palestine.

\section{Conclusion}

Public diplomacy and nation branding are becoming increasingly a la mode and it is crucial to note that there is a shift towards privatization with availability of experts and consultants who provide this service for governments, it is now being argued that a "brand attaché" or maybe a "Brand Unit" might become an essential part of organizational structures at embassies. Both fields of public diplomacy and nation branding are evolving rapidly; they can change instantly according to political, cultural, and social developments. With the growing dynamics of both fields, more cooperation is needed between practitioners and scholars. Public diplomacy and nation branding complete each other and neither can replace the other; public diplomacy was always referred to as "an old art, but a new profession", differentiation is an inseparable feature of branding, as a strong brand identity can differentiate the actual product or company from its competitors. It is widely agreed among nation branding scholars and practitioners that countries and their governments should engage in nation branding to differentiate their countries from others to gain competitive advantages. It is of crucial importance to shed light on the core idea of nation branding that distinguishes it from public diplomacy and that is to identify the "uniqueness" of the country, its people, culture or landscape to identify and draw on features that differentiate "us" from "them", what distinguishes us, as opposed to public diplomacy, which often tries to identify those elements of the history, culture, or people that unite, rather than separate, "us". In nation branding, therefore, the appeal factor (the soft power) is the difference, the otherness, the unique but in public diplomacy it is what is common and shared. 
What is needed to manage our reputation and to better brand for ourselves? We would argue that the following values and criteria are crucial for branding one's nation: credibility, collective work, objectives, investments, and human capital.

It is time for Palestine to tackle the issue of nation branding scientifically and practically to help shape the Palestinian narrative in favor of the Palestinian rights and to avoid a stronger counter narrative. It is time to promote the bright side of Palestine and to bring to the world what makes Palestine unique and attractive, to tell the story that Palestinian nation aspire to tell and not what others have chosen for us for years.

\section{References}

Anholt, S. (2007). Competitive identity: The new brand management for nations, cities and regions. Basingstoke: Palgrave Macmillan.

Gudjonsson, H. (2005). Place brand public diplomacy. Nation Branding. Retrieved from https://doi.org/10.1057/palgrave.pb.5990029

Jaffe, E. D., \& Nebenzahl, I. D. (2001). National image and competitive advantage the theory and practice of country-of-origin effect. Copenhagen: Copenhagen Business School Press.

Nye, J. S. (2004). Soft power: The means to success in world politics. New York, NY: Public Affairs.

Olins, W. (2002). Branding the nation-The historical context. Journal of Brand Management, 9(4-5), 241-248.

Szondi, G. (2009). Discussion papers in diplomacy, public diplomacy and nation branding: Conceptual similarities and difference. Clingendael: Netherlands Institute of International Relations.

Williams, J. (2012). Williams on diplomacy, studies in strategy and communication. London: Indie Books.

Ying, F. (2006). Nation branding: What is being branded? Journal of Vacation Marketing, 12(1), 5-14. 